\title{
Orangetti Squash in Field, Market, and Kitchen
}

\author{
Harry S. Park
}

Additional index words. spaghetti squash, marketing, provitamin A, Israel

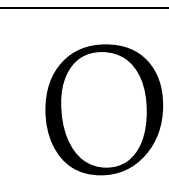

rangetti is a distinct cultivar of spaghetti squash (Cucurbita pepo L.) developed at the Dept. of Vegetable Crops, Agricultural Research Organization, Newe Ya ar Experiment Station, Israel, released in 1986 (Paris et al., 1985 ). Orangetti has a unique combination of features that include attractive orange fruit rind and flesh, contrasting black-green peduncle, and bush plants. Apparently, it is the first vegetable cultivar developed in Israel marketed in the United States under its own name.

Orangetti is a hybrid developed from the open-pollinated Vegetable Spaghetti squash by the backcross method of breeding. The Precocious Fordhook Zucchini breeding line (Shifriss, 1981) was the donor parent of five dominant genes of major effect that were transferred through six generations of backcrossing to Vegetable Spaghetti. These genes include one for bush growth habit (perhaps $B u$ ) and four alleles affecting coloration $B, D, L-1$, and $L-2$ (Paris and Nerson, 1986). Vegetable Spaghetti is homozygous recessive for all five of these genes, resulting in its rank, viney growth and light coloration.

The combination of the dominant alleles $L-1$ and $L-2$ result in the intense coloration of Orangetti (Paris and Nerson, 1986). The $B$ allele results in its orange hue (Shifriss, 1981),

University of Florida, Institute of Food Agricultural Sciences, Agricultural Research \& Education Center, P.O. Box 248, Fort Pierce, FL 34954.

${ }^{1}$ On sabbatical leave. Permanent address: Department of Vegetable Crops, Agricultural Research Organization, Newe Ya ar Experiment Station, P.O. Haifa, Israel.

Florida Agricultural Experiment Station Journal Series no. $R-02281$. 


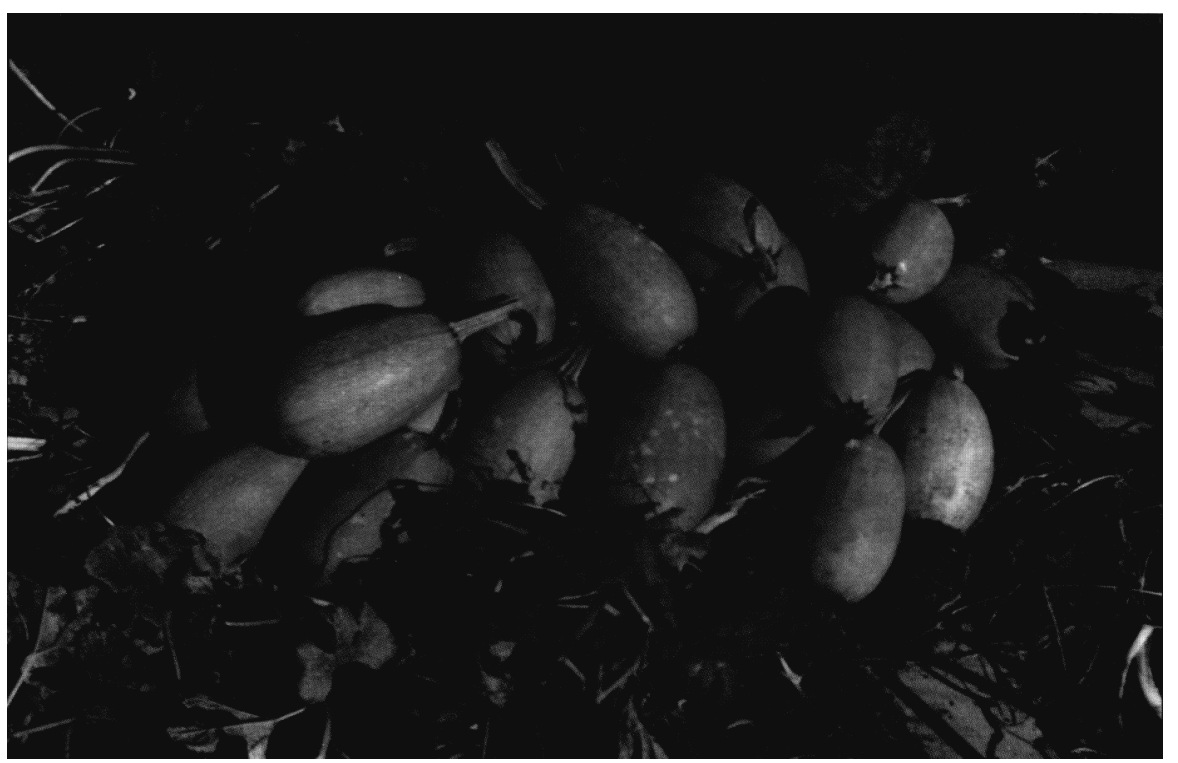

Fig. 1. Orangetti squash upon harvest at the Agricultural Research \& Education Center, Fort Pierce, Fla.

whereas $D$ imparts the blackish color to the peduncles (Paris and Nerson, 1986). The complementary action of the $B$ and $L-2$ alleles results in the orange color of the flesh or spaghetti (Paris, 1988 j.

Orangetti differs from Vegetable Spaghetti in other ways, too. The fruit are smaller and of a sweeter, less-bland taste; smaller, sweeter fruit are known to be effects of $B$ (Schaffer and Boyer, 1984; Shifriss, 1981). About one-fifth less cooking time is required to obtain spaghetti aldente.

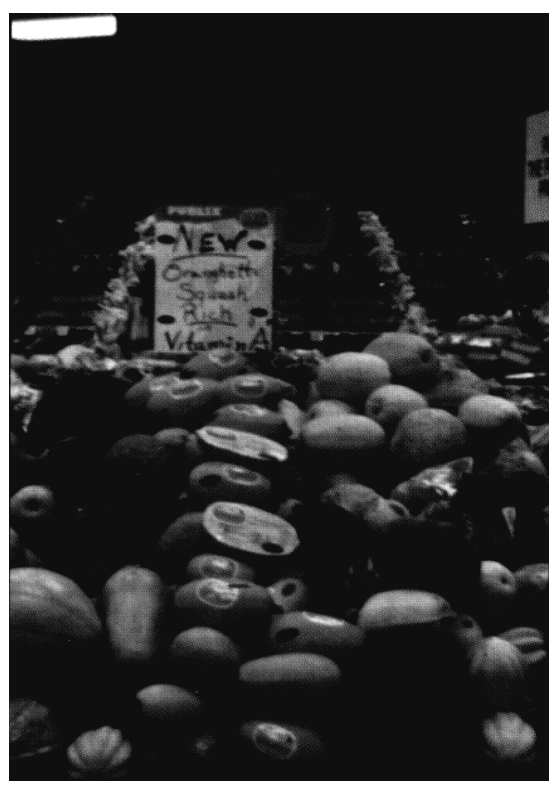

Fig. 2. Orangetti squash in a display along with other quash at the Sabal Palm Plaza, Fort Pierce, Fla., store of Publix Supemarkets, Nov. 1991.
Using the analytical techniques described by Schaffer et al. (1986), the carotene (provitamin A) content of Orangetti was observed to be 3.0 $\mu \mathrm{g} \mathrm{g}^{-1}$ as compared with $0.2 \mu \mathrm{g} \mathrm{g}^{-1}$ of Vegetable Spaghetti. The nearly 15 -fold enhancement in carotene con-
Fig. 3. Orangetti squash after cooking. 1991.

${ }^{2} \mathrm{OG}=$ Orangett $; \mathrm{VSP}=$ Vegetable Spaghett . tent is probably due to the interaction of $B, L-1$, and $L-2$ (Paris et al., 1989).

In trials conducted in Israel at a density of 20,000 plants/ha, Orangetti produced yields of $40 \mathrm{t} \mathrm{ha} \mathrm{ha}^{-1}$, equal to those of Vegetable Spaghetti (Paris et al., 1985). The fruits of Orangetti averaged $900 \mathrm{~g}$, which was smaller than those of Vegetable Spaghetti, but Orangetti produced more fruits.

Orangetti was sown on 4 Sept. 1991 at the Agricultural Research \& Education Center, Fort Pierce, Fla. The crop was harvested once-over 69 days later (Fig. 1). The fruits were placed in a preliminary customer-acceptance trial side-by-side with fruits of Vegetable Spaghetti (and many other squash cultivars) conducted in cooperation with Publix Supermarkets Inc. (Fig. 2).

The trial was conducted at three Publix stores, one in Fort Pierce and two in neighboring Port St. Lucie, with records of sales kept for 3 weeks from initial marketing of the fruits. Promotion with special signs, labels, and cooked samples for tasting presented by a hostess was conducted only in the Fort Pierce store (Fig. 3).

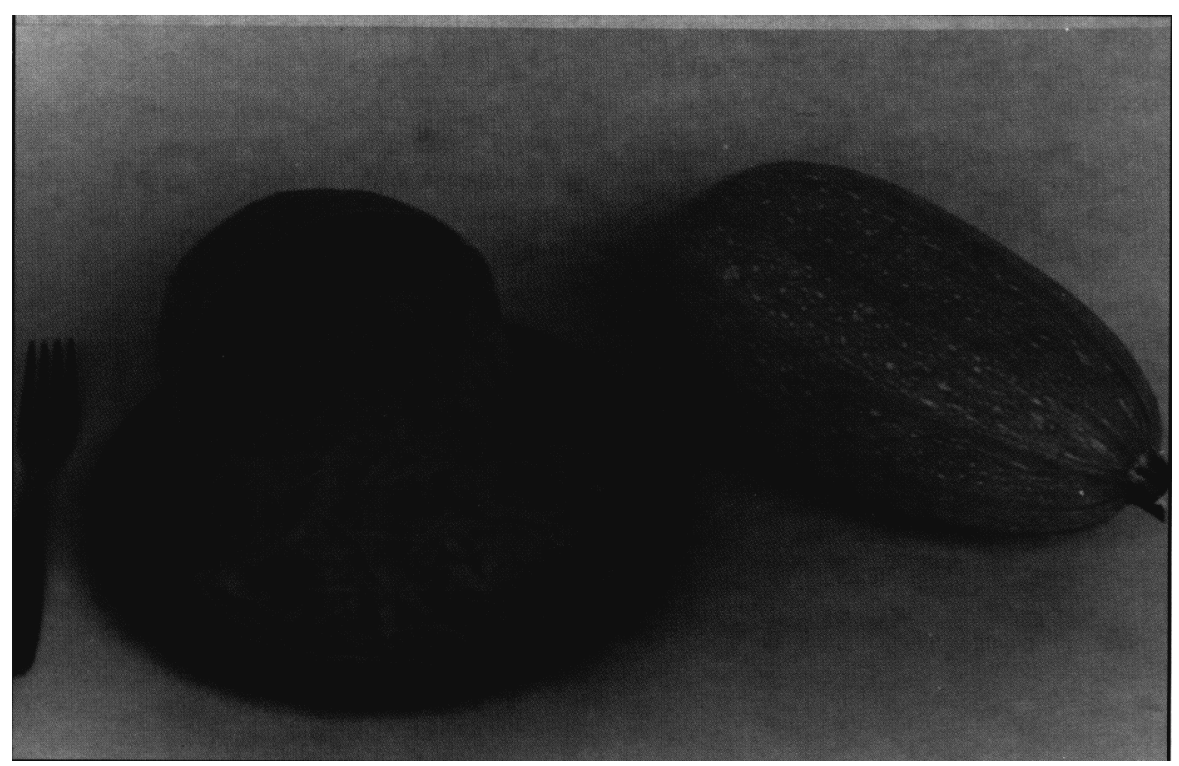

Table 1. Marketing of spaghetti squash ${ }^{2}$ cultivars in stores of Publix Supermarkets, Inc., Nov.

\begin{tabular}{lrrrrrrrr}
\hline & \multicolumn{2}{c}{ No. fruit marketed } & \multicolumn{2}{c}{ No. fruit sold } & & \multicolumn{2}{c}{ Percent sold } & \multicolumn{2}{c}{$\begin{array}{c}\text { Ratio } \\
\text { Store location }\end{array}$} & OG & \multicolumn{1}{c}{ VSP } & OG & VSP & & OG & VSP & OG : VSP \\
\hline Sabal Palm Plaza, Ft. Pierce & 36 & 24 & 36 & 12 & & 100 & 50 & $3: 1$ \\
Port St. Lucie, north & 60 & 8 & 24 & 2 & & 40 & 25 & $12: 1$ \\
Port St. Lucie, east & 90 & 36 & 83 & 14 & 92 & 39 & $6: 1$ \\
\hline \hline
\end{tabular}


In the other two stores, Orangetti fruits were labeled with a Spaghetti Squash sticker containing a recipe, the same as Vegetable Spaghetti fruits. The results of this trial are presented in Table 1. Although the greater quantity of Orangetti fruit as opposed to Vegetable Spaghetti fruit on display at any one time may have favored its sale, the result was overwhelmingly favorable to Orangetti, especially in consideration of its unique characteristics and lack of familiarity to the public. The attractive, intense color of Orangetti, its sweeter flavor, and perhaps its more convenient, smaller size all may have contributed to favorable customer reaction.

Seeds of Orangetti are available from a number of American seed companies or can be obtained from the sole producer, Hazera Seed Co., P.O. Box 1565, Haifa 31-015, Israel.

\section{Literature Cited}

Paris, H.S. 1988. Complementary genes for orange fruit flesh color in Cucurbita pepo. HortScience 23:601-603.

Paris, H.S. and H. Nerson. 1986. Genes for intense fruit pigmentation of squash. J. Hered. 77:403-409.

Paris, H.S., M. Edelstein, H. Nerson, Y. Burger, Z. Karchi, and D. Lozner. 1985. Orangetti and Go-Getti, two new spaghetti squash hybrids (in Hebrew, English abstr.). Hassadeh 66:254 256.

Paris, H.S., A.A. Schaffer, I.M. Ascarelli, and Y. Burger. 1989. Heterozygosity of gene $B$ and the carotenoid content of Cucurbita pepo. Crop Res. 29:11 18.

Schaffer, A.A. and C.D. Boyer. 1984. The influence of gene $B$ on fruit development in Cucurbita pepo. J. Amer. Soc. Hort. Sci. 109:432-437.

Schaffer, A.A., H.S. Paris, and I.M. Ascarelli. 1986. Carotenoid and starch content of near-isogenic $B^{+} / B^{+}$and $B / B$ genotypes of Cucurbita. J. Amer. Soc. Hort. Sci. 111:780 783.

Shifriss, O. 1981. Origin, expression, and significance of gene B in Cucurbita pepo. J. Amer. Soc. Hort. Sci. 106:220 232. 